fame as a morphologist is world-wide. He deeply studied the problems of evolution and wrote at length on them. His "Origin of the Fittest" and "Primary Factors of Organic Evolution" are well known.

As we come downward the stream broadens, and it becomes impossible to do justice to all within the limits of a summary like this. At Harvard, Professor Dwight has worthily worn the mantle left by Prof. O. W. Holmes. His "Anatomy of the Head," "The Identification of the Human Skeleton," and "Frozen Sections of a Child," are well known.

Prof. C. S. Minot has made some remarkable investigations in embryology, especially with regard to the structure of the placenta. His large treatise on "Human Embryology" has deservedly become a generally accepted text-book.

At Cornell University, Professor WILder has for many years past made a special study of the microscopic anatomy of the brain, but he is best known by his efforts to reform anatomical nomenclature. In New York, Dr. HeItzmans, an adopted citizen, was the author of one of the most successful anatomical atlases that has ever been prepared for the use of students, but is perhaps more famous for his attack on the cell theory as commonly received, teaching that all the cells of the body are connected together by intercellular bridges, a doctrine that has recently received a certain amount of confirmation. Dr. F. D. WEIsse published one of the most valuable of the many dissectors, illustrating it with unusually fine engravings. Prof. Geo. S. HunTINGTON is the author of a number of myological papers of great merit.

In Philadelphia, Dr. Geo. B. McClestaA has published a work on "Regional Anatomy" that is one of the best extant; Dr. W. W. KEEN has edited, with conspicuous success, several editions of GRAY's “Anatomy," and Dr. Piersol is well known by his fine work on histology. One of the foremost morphologists of the period was Dr. Ryder, whose untimely loss is deplored by all lovers of pure science.

In Baltimore, the work of Dr. MaLL and of Dr. BARKER of the Johns Hopkins University is attracting attention.

In Washington, the collections of the Army Medical Museum have done much to advance anatomical science, especially along the lines of pathological anatomy. Among the important works that have issued from this source is a memoir upon the human remains found in the Salado Valley, by Dr. Washington MatThews.

Frank BaKer.

\section{PROGRESS IN PATHOLOGY AND BACTERIOLOGY.}

At some time, it has been said of each of the several medical sciences that its birth and its fosterage to greatness were brought to issue by a single nation. It is a delight of the French to proclaim that France, through her mighty son, Pasteur, gave bacteriology to the world, and the Germans are chiseling high upon the adamantine pyramids of fame a legend of RUDOLPH VIRCHOW, father and fosterer of the modern science of pathology.

As to America, her part in the development of the basal sciences of medicine had until recently been small, the reasons for which are to be sought in the laws of environment. Her genius, attacking the nearest duty, had devoted itself to the application of foreign-wrought theoretic knowledge in the execution of practical works, and incidentally in the construction of useful sciences. FRANKLIN, applying physical science to the uses of man, made of the lightning of the storm a torch-bearer and a beast of burden. Morton, applying old laws of chemics and physiology, made painless surgery a realization and subdued the terror -more dreaded than the grim visage of death itself. MCDoweLL, seeking the conquest of pain, applied in an emergency his Scotch anatomic learning. Sims applied a theorem of physics, BatTey and EMMETT applied principles of mechanics and gynecology which went forth from America to Europe; a splendid fullblown science came into life.

Thus we see that in the distant past each of the sundry medical sciences seems to have had a more or less distinct national or provincial origin and development. But whatever may have obtained in former time, in the present outlook geographic limitations in science are unknown. Within the last few years America has brought to the sciences of bacteriology and pathology contributions which, in vastness of import, are not second to those of any other country. In 1887 the Americans, Salmon and SMith, upset at one brilliant stroke all of the then existing hypotheses bearing on artificial immunity. Through their discovery it became known that immunization is possible without the action of living bacterial matter; that an immunity may be secured in a purely chemic way. They suc. ceeded in rendering doves immune against hog cholera by inoculations of bacterium-free solutions of the metabolic products of hog cholera cultures. With this discovery the entire question of artificial immunization was thrown into the province of chemistry, and there began the long line of investigations which have led to successful serum therapy, to the antitoxin treatment for diphtheria, tetanus, etc. BEHRING and Rovx builded upon the works of SALMON and SMITH. Without the American discovery, BeHRING could not have given his announcement to the Budapest congress.

Nuttall, who disclosed that many species of bac. teria are killed by a mixture with fresh blood, and Sternberk, who overthrew the theories of Pasteur and Chavveau, have had original parts in the development of a rational and lasting theory of immunity. To the Americans-Welch, STERnberg and Ostar - the world of medicine is indebted for its riper knowledge of the pathology of malaria. Our understanding of the pathology, bacteriology and antitoxin therapy of diphtheria has been broadened and benefited by the way-breaking works of Prudden, Biggs, Abbott, Flexner, Dunham, Koplik, Councilman, Morse and Emerson. Within the decade KLebs of Chicago has given us new knowledge of yellow fever, and VAUGHAN his epoch-making studies of nuclein and nuclein therapy. Dunham has exhaustively investigated the nature of the bacillus aerogenes capsulatus, and WELCH and FlEXNER have discovered the 
relationship between this bacterium and air embolus. COLEY has originated and elaborated his mixed-toxin treatment of inoperable neoplasms. ROsWeLl PARK has taken up the work of establishing a parasitic etiology of cancer, and SENn has labored originally and pro. lifically on the pathology of tumors.

These are a few of the captain jewels which Americans have placed in the carcanet of bacteriologic and pathologic science within the past ten years. May we not hope, in view of growing national, State and municipal support of bacteriologic and pathologic research, that treasures more vast and more dazzling will be brought out by Americans in another decade, when our sun shall have more fully risen.

\section{J. Rilus Eastman.}

\section{PROGRESS IN OPHTHALMOLOGY.}

To one even slightly acquainted with the subject it $P$ will at once be evident that the space here assigned to an attempted enumeration of purely American additions to ophthalmology must limit such a compilation to a mere catalogue of a few of the contributors and contributions to ophthalmic science. An entire issue of this journal would hardly suffice for a proper treatment of the subject.

In the early part of the century, America took a small but active part in the development of ophthal. mology. George Frick's Treatise on "Diseases of the Eye," published at Baltimore in 1823, and a later edition, London, in 1828, is the first large addition to ophthalmic literature. Next to Saunders' work it was in this early day considered, even in England, to be the best book on the subject. For the following twenty-five years only American editions or translations of British or otber foreign works were accessible to the profession here. In 1850, however, Henry Howard issued, from Montreal, his work on the "Anatomy, Physiology and Pathology of the Eye," a book of 517 pages. In it, among other things, he describes and pictures (page 436) his own invention, an arrow-head knife for the removal of cataract by an easy method. Some years afterward Williams of Boston, MittenDORFF of New York, and others published works on the diseases of the eye. It was, however, reserved for H. D. Noyes of New York to publish (1881-1890) the most compiete and most original treatise on this subject hitherto written in America. Since the first edition of this book, numerous other purely American text-books of ophthalmology have been printed and they compare most favorably with foreign treatises. Of these "A System of Diseases of the Eye," by W. F. Norris and Charles A. Oliver of Philadelphia, requires special mention. This work may well be regarded as the English equivalent of the GraEFESaEmisch Handbuch and the "Traite Complet" of DE WECKER and LANDOLT.

Of periodical literature, we now have our just share, although the first magazine-the original American Journal of Ophthalmology-was not issued until July, 1863. The editor was Julius Bomberger of New York. It became defunct in 1864 , but was soon succeeded by the Archives of Ophthalmology, edited by
Herman KnapP of New York. This magnificent periodical has for twenty-five years held, and still occupies, the foremost rank among English ophthalmic periodicals. If the distinguished editor had done no other work for American ophthalmology than that in. volved in editing the Archives, he would have earned undying fame, and our lasting gratitude. Other flourishing but less prominent publications are the American Journal of Ophthalmology, first issued in 1883, by ADOLF Alt of St. Louis; the Annals of Oph. thalmology, founded in 1891 by JAMES P. PARKER of Kansas City, and the Ophthalmic Record, begun the same year by G. C. Savage of Nashville, Tenn.

Among the older ophthalmologists must be mentioned ISAAC HAYS of Philadelphia, the first editor of the the American Journal of the Medical Sciences and a voluminous writer on ophthalmic subjects in the still earlier Philadelphia Journal of the Medical and Physical Sciences, 1826 and 1827. His is the well-known Hays' knife-kneedle, pictured in BuLL's edition of Soelberg Wells' treatise (p. 339, 1855), regarded by many as superior to all modern instruments of the kind. In the former journal for November, 1831, will be found one of the earliest accounts-by H. MoRTON-of the relations of accom. modation to convergence. In the American Journal of Medical Sciences for April, 1845, will be found an original essay on the subject of "Color Blindness," by Earle. It is highly probable that an American should share with Stromeyer and Diffenbach the honor of devising and making the first operations for the relief of squint. Aтwell (Phila.Med. Examiner, February, 1842) tells the following story: "In the year 1812-13 I attended courses of surgical and anatomic lectures delivered before the medical school of Brown University by WILLIAM INGaLLS, then the professor of anatomy and surgery in that institute; being sub. ject myself to this infirmity (strabismus) Dr. INGALLS took frequent opportunities to explain to me the method of its surgical cure-he did this by dissection of the eye itself-explanation of the power and disposition of the several muscles appertaining to that organ, and showed me how by a division of one or more of them the eye might be brought to its proper place. In my own case I know he proposed to divide the rectus internus. So strongly was I impressed with the practicability and success of this operation that I strongly urged my father to permit me to submit to the operation; but upon the nature of the operation being explained to him bedeclined the permission because he feared the effect might be to turn the eye the other way."

So, also, Professor Dewey of Union College (1849), has a strong claim to recognition as the discoverer of hypermetropia - prior to DONDERs - called by him neomacropia (Am. Journal of Science and Art, vol.viii). BLACKMAN's operation for the relief of spasmodic entropion, said to be superior to HIMLY's, is described in the New York Lancet for June, 1842. Among the early methods of cataract extraction, the New Eng. land Journal of Medicine $(1819,126)$ contains the following by GiBson of Baltimore: "The iris was' in the first place dilated by the application of atropa 